\title{
LEGAL ISSUES
}

An institution of higher education is similar to a small city, which means that legal issues in higher education relate to an institution's students, faculty, staff, alumni, and community and involve every facet of its mission, such as teaching, research, service, global reach, community engagement, and online presence. Legal issues that intersect with higher education include but are not limited to tortious liability, constitutional constraints for public institutions, compliance with administrative and statutory law, contractual obligations, employment discrimination, intellectual property, and business relationships, among others. Since the potential for legal liability and large monetary damages has increased concerns for institutions of higher education since the 1960s, it is vital for institutions and their employees to understand applicable laws.

This entry provides an overview of legal issues pertinent to higher education in the United States and internationally.

\section{Higher Education Law in the United States}

Institutions of higher education have various liabilities that they must mitigate, such as tortious liability (fault resulting from injury caused by intentional acts or negligence), contractual liability (unmet responsibility previously agreed upon), and constitutional liability (accountability under state and federal constitutions), among others. Institutions also need to be aware and understand federal and state employment law, nondiscrimination and affirmative action laws, and local laws and business regulations. Sources of laws for institutions of higher 
education in the United States include state and federal constitutions, state and federal statutory law, state and federal case law, state and federal administrative rules and regulations, and, in some cases, foreign and international law. Institutions and its employees must also abide by institutional policies.

The U.S. Constitution is the highest legal authority in the United States, and state and local laws may not conflict with its provisions. The Constitution prescribes fundamental individual rights afforded to persons within the jurisdiction of the United States, such as the freedom of speech and of religion, , the right to reasonable searches and seizures, due process rights, and equal protection under the law, among others. First Amendment rights have been in the spotlight on American campuses with cases involving controversial speakers, racist flyers, and protest demonstrations. While members of the university and community have free speech rights, these rights can be restricted by place, time, and manner. All restrictions must be contentneutral, such as imposing limits on the noise level of speech, capping the number of protests occupying a given forum, setting time of day restrictions, or limiting size and placement of signs on government property. These restrictions must satisfy a three-prong test outlined in Ward $v$. Rock Against Racism (1989): (1) the regulation must be content neutral; (2) it must be narrowly tailored to serve a significant governmental interest; and (3) it must leave open ample alternative channels for communicating the speaker's message.

In addition to these restrictions, campuses must balance free speech with campus safety concerns and an inclusive learning environment. The public forum doctrine was recognized in the U.S. Supreme Court case Hague v. CIO (1939) and includes a three-tiered categorization: (1) traditional public forum, (2) limited public forum, and (3) non-public forum. The traditional public forum includes speech on public streets, parks, and sidewalks, and can be limited by 
restrictions related to time, place, and manner. The limited public forum is most applicable to higher education spaces and are nonpublic forums that have been designated by the government as open to certain groups or topics. As long as the speaker or speech complies with the limits set by the government as to how the public space is used, the government is subject to same restrictions as a traditional public forum, such as those related to time, place, and manner. Examples on campuses include free speech zones, democracy plazas, or other spaces that are available for students to congregate and assemble. The U.S. Supreme Court has found that while universities are obliged to protect First Amendment rights, they also have other institutional goals, such as education, financial efficiency, and safety, which may affect the expression of those rights (Widmar v. Vincent, 1981).

First Amendment rights also extend to principles of academic freedom, promotion and tenure, and public employee speech. For example, the U.S. Supreme Court has found that the foundation of academic freedom in education is the ability for professors to teach and research without any governmental interference. In Shelton v. Tucker (1960), the U.S. Supreme Court stated, "The vigilant protection of constitutional freedoms is nowhere more vital than in the community of American schools." As a result, the "right of freedom of speech and press [from the First Amendment] includes ... freedom of thought, and freedom to teach - indeed the freedom of the entire university community" (Griswold v. Connecticut, 1965). The American Association of University Professors (AAUP) have published the 1940 Statement of Principles of Academic Freedom and Tenure to protect governmental and/or institutional interference of a scholar's research and teaching. Other constitutional issues include the Fourth Amendment's guarantee of reasonable search and seizure and the Fourteenth Amendment's due process and equal protection clauses - both also key in higher education. 
While the U.S. Constitution does not delineate specific powers in education to the federal government, Congress is able to impact various aspects of education through its spending powers exercised by means of legislation. Examples include the protection of student privacy through the Family Educational Rights and Privacy Act (FERPA); the protection of civil rights through Title VII of the Civil Rights Acts of 1964, Title IX of the Education Amendments of 1972, Section 504 of the Rehabilitation Act of 1973, and the American Disabilities Act; and student safety, through the Crime Awareness and Campus Security Act, also known as Clery Act. The Clery Act requires institutions of higher education to comply with a number of provisions, among them are to collect, classify, and count crime statistics, issue campus crime alerts, and publish an annual report. In the higher education context, other federal statutes protect employee rights (e.g., the Occupational Safety and Health Act, Fair Labor Standards Act, and Family and Medical Leave Act).

Title IX of the Education Amendments of 1972 has provided a roadmap to addressing a variety of legal issues among underrepresented populations based on sex and gender. It states that "[n]o person in the United States shall, on the basis of sex, be excluded from participation in, be denied the benefits of, or be subjected to discrimination under any education program or activity receiving Federal financial assistance." Title IX has helped address sex discrimination in high school and collegiate athletics and was referenced by the U.S. Supreme Court when it held that sexual harassment is a form of sex discrimination (Meritor Savings Bank v. Vinson, 1986). President Barack Obama's Administration referenced Title IX when it issued a "Dear Colleague" Letter guidance to educational institutions to redress sexual assaults as a civil rights issue and to encourage LGBT rights and protections. In a $7^{\text {th }}$ Circuit Court of Appeals case, Hively v. Ivy 
Tech Community College (2017), Title IX was referenced alongside Title VII of the Civil Rights Act of 1964 to find that sex discrimination protections extend to LGBT individuals.

Since the U.S. Constitution does not specifically refer to education, these powers are relegated to the states, and state constitutions establish the organization of their public institutions of higher education. State law also regulates private institutions of higher education. State statutory and administrative law are important to understand and comply with where federal law does not have purview. State law can also mandate that institutions comply with more requirements than federal law, provided it does not conflict with federal law. Some areas in which state law has impacted higher education include in-state resident tuition for undocumented and DACAmented students and nondiscrimination laws based on gender identity and sexual orientation. DACAmented students have an approved Deferred Action for Childhood Arrivals (DACA) application from the United States Citizenship and Immigration Services (USCIS). This program was created by President Barack Obama through executive order to allow certain eligible undocumented youth to be free from deportation and have certain benefits, such as employment authorization. In 2017, President Donald Trump announced that he would rescind the executive order. This program is in limbo awaiting the judicial appeals process.

Since non-resident U.S. nationals pay out-of-state tuition, Section 505 of the Illegal Immigration Reform and Immigration Responsibility Act of 1996 (IIRIRA), a federal statute, prohibited undocumented resident students from benefitting from resident in-state tuition. As a result, many states began to rectify this consequence through executive order or legislation. Since 2001, nineteen states have issued an executive order or passed legislation to allow undocumented students and/or Deferred Action for Childhood Arrivals recipients to receive some kind of in-state tuition benefit. Six states have prohibited in-state tuition and/or enrollment 
all together, and six states provide state financial aid. Federal financial aid has been prohibited for non-U.S. nationals since the passage of the Higher Education Act of 1965. While federal law provides a baseline, as long as state laws comply with federal law, they may address areas not covered by it; however, the result is a patchwork of state and federal laws that require practitioners to piecemeal together to understand.

\section{International Higher Education Law}

Laws in other countries and international treaties are important to consider as students, faculty, and staff are more mobile in the $21^{\text {st }}$ century than ever before. As students and faculty travel to foreign countries, institutions engage in business transactions in foreign countries, and educational programs are established in foreign countries, legal issues arise.

Potential liability issues may arise in study abroad or exchange programs. As students, faculty, and staff study or work abroad, institutions need to understand to take reasonable steps to protect them. Institutions must conduct due diligence to assess risks both in the home and host country and address those concerns. Some concerns with studying abroad may be political unrest, underage consumption of alcohol or other controlled substances, or challenges to participating fully as a result of a disability.

Studying or working abroad may require compliance with licensure and registration with local authorities. Local laws may require the establishment of a separate legal entity, which will have separate tax and business consequences. For example, if institutions decide to start a branch campus or office, they must register and comply with local laws. U.S. institutions may also enter into partnerships with local institutions, but when entering into business partnerships with foreign institutions or companies, choice-of-law issues may arise if there is a dispute. It is 
important to examine whether the contract specifies under which law the contract will be interpreted. Litigation — both the laws and the procedures - in a foreign country can look very different. In addition, hiring foreign employees will require compliance with relevant local and national employment and tax laws. Different countries have different requirements.

International agreements and treaties can have legal implications for institutions in a variety of areas. For example, the World Trade Organization's Agreement on Trade-Related Aspects of Intellectual Property Rights (TRIPS) prohibits the unauthorized copying of copyrighted works, such as textbooks. Other copyright agreements include the Berne Convention and the Universal Copyright Convention. In addition to textbooks, these agreements may apply to faculty research, patents, trademarks, and copyrights. It is for the administration of an institution of higher education to understand and determine how work created abroad or with foreign faculty is owned and credited.

The Bologna Agreement, also known as the Convention on the Recognition of Qualifications Concerning Higher Education in the European Region, was initially signed in 1999 by 29 European countries and now signed by fifty countries, including the United States, created a unified system for evaluating and recognizing foreign degrees and credentials. Beside the Bologna Agreement, other EU regulations also impact international higher education; for example, the European Union's (EU) General Data Protection Regulation (GDPR) has implications for foreign institutions serving those in EU member states, whether through a physical or online presence. The GDPR protects personal information of EU residents and provides certain rights to access and delete personal data acquired by organizations. The General Agreement on Trade and Services (GATS) signed in 1995 helped to make it easier to offer services, including education, across borders. 


\section{Final Thoughts}

Legal literacy is critical and important for higher education leaders, researchers, scholars, and practitioners as there are many implications that impact not only institutional liability but also the collegiate learning environment. Since the law is fluid and ever-changing, it is important to stay informed regrading changes in laws that affect the higher education landscape. The law not only dictates what is prohibited and permitted, but the law also often seeks to advocate, uplift, and advance the rights of underrepresented peoples.

David Hòa Khoa Nguyễn and Jon Iftikar

\section{FURTHER READINGS}

Deardorff, D. K., de Wit, H., Heyl, J. D., and Adams, T. (Eds.) (2012). The SAGE Handbook of International Higher Education. Washington, D.C.: SAGE Publishers.

Fossey, R., \& Eckes, S. (Eds.) (2015). Contemporary Issues in Higher Education Law ( ${ }^{\text {rd }}$ Ed.). Cleveland, OH: Education Law Association.

Kaplin, W. A., Lee, B. A., Hutchens, N. H., \& Rooksby, J. H. (2019). The Law of Higher Education $\left(6^{\text {th }}\right.$ Ed.). San Francisco, CA: Jossey-Bass

Nguyen, D. H. K. (2018). Jim Crowing Plyler v. Doe: The Resegregation of Undocumented Students in American Higher Education through Discriminatory State Tuition and Fee Legislation. Cleveland State Law Review, 63, $355-371$.

Nguyen, D. H. K., \& Ward, L. W. M. (2018). Innocent until proven guilty: A critical interrogation of the legal aspects of job fit in higher education. In Reece, B. J., Tran, V. T., DeVore, E. N., \& Porcaro, G. (Eds.). Debunking the Myth of Job Fit in Higher Education and 
Student Affairs. Sterling, VA: Stylus Publishing, Inc. 